\title{
A Technological Innovativeness Measurement Framework: A Case Study of Technology Based Indonesian Companies
}

\author{
Leo Aldianto ${ }^{a^{*}}$, Jann Hidajat Tjakraatmadja ${ }^{a}$, Dwi Larso ${ }^{a}$, Ina Primiana ${ }^{\text {b, Grisna Anggadwita }}{ }^{c}$ \\ ${ }^{a}$ School of Business and Management - ITB, Indonesia \\ ${ }^{b}$ Universitas Padjajaran, Indonesia \\ 'Telkom University, Indonesia
}

\begin{abstract}
The measurement of innovation has been developed by various previous studies with a specific focus and goal. However, the existing measurement framework still cannot be applied all that easily by companies in Indonesia for assessing, evaluating, and improving their innovations. This study aims to propose a measurement framework using a multiple case study approach. Cases were selected from companies in the pharmaceutical and information and communications technology (ICT) industries because they contribute substantially to the manufacturing sector and both are vital to Indonesia. The results of this study indicate that the measurement model of innovation consists of technological innovation and the management of technological innovation. There are three phases in the technological innovation process which include the initiation phase (conceiving ideas and acquiring information, then transforming it into knowledge), the development phase (validating knowledge and checking its appropriateness), and the diffusion phase (getting users' feedback and Go \& scaling up ). Meanwhile, the management of technological innovation consists of having a strategy, the necessary resources, and operation . The analytical generalization of this study is still considered to be limited, so further studies are needed to analyze cases in other industrial sectors. In addition, a quantitative study is required to construct a measuring instrument for the variables proposed in this study.
\end{abstract}

Keywords: measurement framework, innovativeness, innovation activities, case study, management of innovation, Indonesia

JEL Classification: L26, O14, O32 


\section{Introduction}

Various companies compete to make innovations for the continuity of their businesses. Smart phone producers, such as Apple and Samsung, depend on constantly adding new features to their products. Automotive companies are working on the next generation of green and electric cars. Scholars and managers generally agree that innovation is an important source of corporate competitive advantage (Essmann and du Preez, 2009; Herrera, 2015; Hinterhuber and Liozu, 2014; Brem et al., 2016).

Technological innovation is a topic of interest for countries and companies. For example, the UK Department of Trade and Industry considers technological innovation to be one of the drivers of national competitiveness, and encourages companies to develop and improve their innovation processes' management and performance (Chiesa et al., 1996). Countries in Asia make various efforts to foster technological innovation, so they can be more competitive. For example China's equipment manufacturing industry, which has grown significantly in the period from 2006 to 2010, was challenged to develop its own innovation by improving its technological capability and management of technology (Wu et al., 2012). South Korea is also well known as a country that can catch up with the developed countries through technological innovation. Companies such as Samsung and Hyundai have their competitive technologies and have become major players in the electronics and automotive industries (Paik and Chang, 2015).

Indonesia has also recognized the importance of innovation and launched several programs to support innovation. In mid2011, Indonesia launched the Master Plan for the Acceleration and Expansion of the Economic Development of Indonesia (Master Plan Percepatandan Perluasan Pembangunan Ekonomi Indonesia - MP3EI), wherein one of the basic principles was a shift towards better productivity, innovation and creativity, which is driven by science and technology.

Based on data from the Global Competitiveness Report 2019, Indonesia is ranked 50th overall and 74th in the Innovation pillar (out of 141 countries) (World Economic Forum, 2019), which means Indonesian companies are not seen as innovative companies. Asian companies that are performing well in the world are shown by the presence of 15 Asian companies in the list of the 50 most innovative companies (Arndt and Einhorn, 2010), but there were no companies from Indonesia. The former secretary of the Ministry of State-Owned Enterprises has observed that Indonesian companies rarely make major innovations (Didu, 2010) and it is widely acknowledged that the ability of Indonesian companies to innovate and to compete in innovative industries is weak.

Companies need to understand and improve their abilities to innovate by measuring the maturity of an innovation, and various measurement frameworks have been developed. However, no approach has yet been found that can be easily used by Indonesian companies to assess their innovations and help them innovate (Didu, 2010; Aldianto et al., 2012). This study is intended to propose a measurement framework that captures the activities undertaken during the innovation process, which will lead to a better understanding of the innovativeness of a company (Cooper and Edgett, 2012; Phan and Kocaoglu, 2014; Guo et al., 2019). This study tries to find gaps that a company's measurement framework can be identified with through its activities, 
tools and facilities, and its human resource capabilities and competencies.

This article continues with a section on the study's background and research question, which describes the study's background leading to the research question. Then a section on the conceptual framework that illustrates the constructs included for the measurement. The research context is explained in the research setting's section. Meanwhile, the research's design and methods are in the section titled "Research methodology." Finally, the findings are presented and discussed in the sections covering the findings and discussion.

\section{Literature Review}

Read (2000) observed that there were various kinds of innovations, and no single generally accepted definition of innovation existed, the key characteristics of an innovation include newness, usefulness, and both the processes' and outcomes' perspectives are involved. So, the following definition, which includes broad types of innovation, from the Organization for Economic Co-operation and Development $(\mathrm{OECD})$ is used:

"An innovation is the implementation of a new or significantly improved product (good or service), or process, a new marketing method, or a new organizational method in business practices, workplace organization or external relations." (OECD, 2005)

Researchers defined innovativeness both in terms of an organizational capability (Ettlie et al., 1984; Tsao and Chen, 2012; Choi and Williams, 2016; Bature et al., 2018) as well as the quality of a product, as a result of innovation (Kim et al., 2012; Smith et al., 2012). According to Ettlie et al. (1984), the dichotomy of innovation in organizations is to introduce how organizations adopt radical or incremental innovations. According to Jugend et al. (2018), the difference between incremental and radical innovation is not always clear. Tushman and Romanelli (1985) described incremental innovation as changes that promote the status quo, whereas radical change is a "reorientation process in which patterns of consistency are fundamentally rearranged." They describe the organizational change hierarchy based on how widely the changes affect the place or decisions of the organization. Radical innovation includes high-level innovation that serves to create new industries, products, or markets (Menguc et al., 2014; Sheng and Chien, 2016). These changes are based on very significant technological advances, so there are no increases in scale, efficiency, or design that can make older technology competitive (Tushman and Anderson, 1986). According to Ettlie et al. (1984), a new technology for organizations, which requires both throughout (process) as well as changes in output (production or service), and allows the magnitude or cost of the change required by the organization to be sufficient to guarantee the goals of radical innovations, as opposed to incremental innovations.

This study focuses on the innovation processes of companies; hence, definitions of innovativeness as an organizational capability are more appropriate. The following definition is used because it is concise and implies the actual activities: company innovativeness is the tendency of a company to innovate or develop new products (Ettlie et al., 1984).

\section{Innovation Measurement}

There are various ways to measure innovation and it is generally recognized that 
currently there is no widely accepted framework to assess the innovativeness of companies (Adams et al., 2006; Phan, 2013). In the so-called traditional methods, innovation's measurement is done using indirect indicators such as $\mathrm{R} \& \mathrm{D}$ and patent data, while new methods use direct indicators such as innovation counts and company-based surveys (Becheikh et al., 2006; Smith, 2005). An innovation count collects the significant innovations, while the company-based surveys collect data on the innovation process as well as the output of any innovation. Many surveys follow the standard innovation survey developed by the OECD and Eurostat, the Oslo Manual, which attempts to collect the following data: the general process of innovation, the innovations themselves, the influencing factors of the innovation, and the outcomes of innovation (OECD, 2005). Both traditional and new measurement frameworks are usually used to compare the innovation performance of companies across industries or countries (Smith, 2005), leading to efforts from many researchers to develop measurement frameworks that focus on company-level innovations.

Some researchers were interested to measure the driving (input) factors that lead to innovation results. Capaldo et al. (2003) linked four types of resources (i.e. entrepreneurial, human, external networks, and economic resources) which are managed and utilized by companies with their innovative capabilities and Martensen et al. (2007) identified the important factors such as leadership, innovativeness, partnership, and people and resources to improve an innovation's results. Some other researchers focused on output factors as measurement items for innovativeness in a company, such as measurement of the product's innovation performance in terms of the degree of the innovation's suc- cess (efficacy) and the effort to achieve that (efficiency) (Alegre et al., 2006), or measurement of the revenue from new products, the market share of new products, and products that are new to the world to indicate companies' innovativeness (Phan, 2013).

\section{Innovation Measurement Framework}

Other researchers have proposed more comprehensive frameworks that account for some combinations of inputs, processes, and outputs. The Boston Consulting Group (BCG) conducted surveys over several years to identify companies' measurement practices in the area of innovation, where they had found that only $46 \%$ of the participating senior managers stated that they did measurements of innovation and only $32 \%$ were satisfied with their existing measurement methods (Andrew et al., 2009). Though various metrics were mentioned in the surveys, the companies clearly favored output measures, such as overall company profitability, overall customer satisfaction, and incremental revenue from an innovation. They were followed by some process measures, i.e. time to market and ideas' generation, and input measures like R\&D efficiency and the portfolio's condition.

Saunila and Ukko (2012) proposed a framework to measure the innovation capability of a company by measuring its innovation potential, its innovation process activities, and the result of its innovation activities. They also linked this innovation capability with business performance. Another researcher, Chuang (2005), considered the measurement of technological and administrative innovations, using some output indicators and input factors (the resources) respectively.

An important stream of research studied 
innovative capability building, especially in latecomer companies. Dantas and Bell (2009) offered a framework for understanding the knowledge-centered network as part of the development of a company's technological capability to make innovations, while Dutrenit (2000) focused on the process of technological capability building in late industrializing companies and the issues of knowledge management. Bell and Figueiredo (2012) noted that the innovative capability involved two dimensions: technological/physical and organizational. Further, the challenges for latecomers were traditionally divided into the catching up in production capability and the building of innovative capability. However, in his later study, Figueiredo (2014) concluded that companies did not follow a linear path of technology catch-up, they continued with innovative capability building but they could also acquire innovative capabilities at various levels and phases, where they continuously increased their capability and achieved some results along the way. The last study also stated the importance of companies performing several innovation activities besides $R \& D$ activities, to build their innovative capabilities. Further in this stream of innovation as a learning approach, Sutz (2012) emphasized the evaluation of factors such as innovation activities, actors who have knowledge, and what kind of knowledge they have.

Furthermore, several researchers developed a measurement framework with an audit approach. Chiesa et al. (1996) developed a framework for auditing technological innovation's management. They stated that success in innovation is related with good practices in the relevant management processes and organizational mechanisms. They measured four core processes: concept generation, product development, process innovation, and technology acquisition; and three enabling processes that support the core processes: resources, systems and tools, and leadership. However, as they focused on the managerial aspects, they were not very specific in explaining the actual activities during the technological innovation process. Contrary to that, this study takes a basic notion that innovation is determined by the actual activities or the work during the innovation process. Even with these auditing measurement frameworks, a framework has not yet been developed that can help a company to innovate, in the way that ISO certifications guide and improve the process, so companies can get better results, or the capability maturity model (CMM) framework, which was consolidated from the vast experience gained from the development and maintenance processes for software, which initially helped software companies to improve their performance in developing software (Silva et al., 2015).

Adams et al. (2006) developed an integrated framework for the general measurement of innovation's management, which covers both output performance and innovation processes. They collected the fragmented categories of the measurement of innovation and the different measures proposed by scholars in the innovation area, which covered seven categories: inputs, knowledge management, strategy, organization and culture, portfolio management, project management, and commercialization. However they did not consider specific technological innovation processes or the relationships between the seven major processes they identified.

Brophey and Brown (2009) proposed a measurement framework based on empirically identified innovation processes in mechanically-based small and medium manufacturers. They identified the manageable innovation 
practices during the process of innovation (idea generation, idea screening, idea implementation, enabling forces, and barriers to innovation) and proposed an index as an indicator of the elements of those processes. So, their innovation practices are more like the collection of management policies or directions to guide innovation during different phases. These practices can be considered as starting points (inputs) for the innovation process but there is no explanation of what the activities are and which ones contribute to innovation.

Some researchers have developed an innovation measurement framework utilizing the maturity model. Rush et al. (2007) developed an assessment tool to determine four maturity levels in the management of technology in companies, so that the policy makers would be able to create capability-related policies. Essman and du Preez (2009) developed a model to assess the innovation capability in organizations using factors that are important in organizational innovations, and applied the maturity levels concept which led to a framework consisting of three axes: an Innovation Capability Construct, an Organizational Construct, and Capability Maturity. However, there was still a need to apply the maturity level approach to an innovation's measurement that assessed and guided the actual activities when a company made a technological innovation. Considering the gap, this research attempts to develop a framework to measure the technological innovativeness of a company based on identifying and measuring the activities of the technological innovation's processes and their management. In other words, this research is set to answer the questions about how the innovativeness of a company is measured, in terms of the activities during the innovation process and the management of those activities.

\section{Conceptual Framework}

The literature has shown that innovation is measured by evaluating its inputs, processes, and outputs. This study focused on measuring the innovation process, so that it can be used as a guide by companies to help them innovate. This study builds on the literature focusing on the innovation processes, which states that innovations are determined by two groups of factors: the physical aspects that are represented by the innovation activities (both R\&D and non R\&D activities) and the resulting products or services, and the orga-

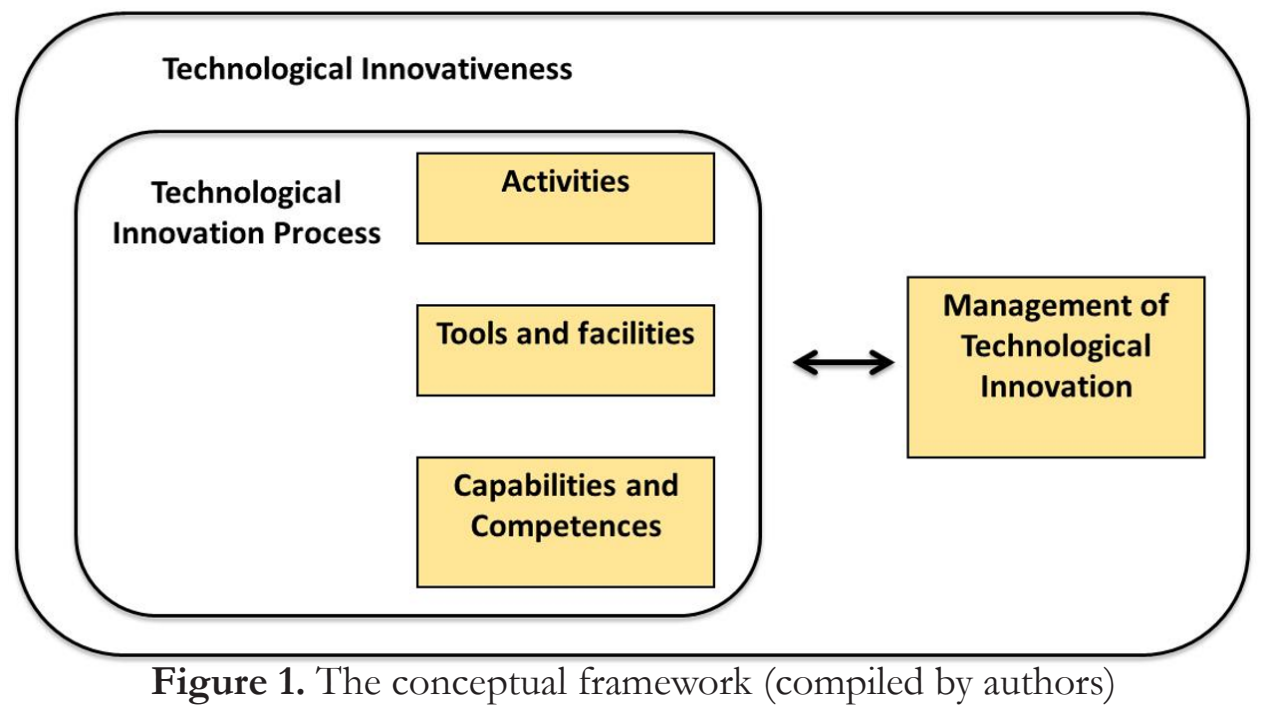


nizational aspects (Adams et al., 2006; Bell and Figueiredo, 2012; Brophey and Brown, 2009; Chiesa et al., 1996; Sutz 2012). However, they differ in the variables they use for the two groups and they do not consider specific technological innovation processes. The conceptual framework (depicted in Figure 1) focused on technological innovations for the production of goods and the provision of services.

Based on Figure 1 above, technological innovativeness consists of two areas: the technological innovation process and the management of technological innovation, in which the two areas influence each other. The literature considers the technological construct, which consists of activities and supporting tools, and facilities, to be a transformation mechanism and service platform, and competencies and abilities are the driving components. Based on the conceptual framework in Figure 1, this study attempts to identify specific variables for measuring the technological innovativeness of Indonesian companies using multiple case study research.

\section{Research Setting}

This study focuses on the manufacturing sector due to its substantial contribution to the Indonesian economy, yet at the same time it faces a big challenge to improve its contribution to Indonesia's competitiveness by moving up the regional value chain and adding more value through innovation (Ministry of Industry, 2013). The manufacturing sector contributed $20.8 \%$ to Indonesian GDP in 2012, though this had declined from 20.92\% in 2011 (Ministry of Industry, 2013). More alarmingly, the growth of Indonesian manufacturing was much lower than before the crisis in 1998. While the growth was about $12 \%$ in early 1990 , the growth in the 2000 s has only been about $5 \%$, according to the World Bank (2012). The latter report also showed that the recovery of Indonesian manufacturing was lagging behind other countries such as Malaysia, Thailand, and South Korea.

This study focused on the pharmaceutical industry and ICT industry because these two industries are the main contributors in the manufacturing sector and are very important to Indonesia. Indonesian pharmaceutical companies currently only focus on finding off-patent generic medicines, licensing medicines from foreign companies, and producing medicines from raw materials supplied by foreign companies (Sampurno 2007). Increased global and regional competition poses a threat to the industry, such as the single ASEAN market, requiring Indonesian pharmaceutical companies to consider knowledge-based development and increase their R\&D activities to find new medicines. Another fact, based on data from the World Bank, shows that Indonesia's health expenditure per capita, in 2016, was only US\$111.55, compared to Malaysia (US\$ 361.52) and Singapore (US\$2,462.39), so that the pharmaceutical industry has enormous growth potential and deserves to be on Indonesia's priority list (World Bank, 2019).

Meanwhile, the ICT industry has contributed significantly to Indonesia's economic growth. The export value of electronics and ICT reached US $\$ 5.55$ billion between January to August 2019 and ICT expenditure in Indonesia was valued at US\$ 32.8 billion in 2019. However, Indonesian companies produced only 2 to $3 \%$ of the total market sales of telecommunications equipment (Indrayanto et al., 2008), which means that Indonesia imports almost all of its ICT. Hence, the Indonesian government has encouraged 
Gadjah Mada International Journal of Business - January-April, Vol. 23, No. 1, 2021

more local design and manufacturing activities and provided various incentives to increase the local content of the products.

\section{Methodology}

This study identifies specific activities and the related management aspects using empirical data from companies in Indonesia's manufacturing sector, and adopts a qualitative study approach, in which an interpretive approach is used for building the knowledge of innovativeness of a company by observing and interpreting human interactions in real activities. The aim is to obtain a rich picture and deep understanding of the innovation processes in a company and therefore a case study research was selected, wherein in-depth interviews and multiple sources of information are the main sources of the data (Houghton et al., 2013; Yin, 2014; Tetnowski, 2015). Case studies are used to explore a particular phenomenon during a certain period, by gathering detailed and in-depth information using various data collection procedures (Cresswell, 1998). This case study focused on understanding the subject and relevant variables, and did not intend to generalize (Groenland and Dana, 2019). This study used multiple case studies of four companies: two companies from the pharmaceuticals industry and two companies from the ICT industry. The case study research was carried out following Eisenhardt's (1989) approach, being encouraged by clear steps, and was divided in two phases:

- Phase 1: Building a conceptual model using a literature review and an emerging model using case study research.

- Phase 2: Confirming the measurement model with a group discussion and defining the measurement items using the Delphi method.

\section{Cases Selection}

These cases represent two types of product innovation: incremental innovation and radical innovation. This study focused on the pharmaceutical industry and the ICT industry, we submitted requests and conducted studies based on their willingness to participate and disclose data concerning the incremental or radical innovations in their companies. There were four companies that participated in this study: CO1, CO2, CO3, and CO4. This study used codes to maintain the privacy of these companies.

In the pharmaceutical industry, the first type of innovation was represented by the development of a supplement called $\mathrm{Hi}$ Bone at CO1. This supplement utilized a new ingredient, produced by DSM Nutritional Products, and was aimed at preventing and treating osteoporosis in pre \& postmenopausal women. CO1 had a follower strategy to be the first to market a generic product by copying the existing product which had an expired patent or by making a product using the raw materials offered by foreign companies. CO1 made products, medicines or supplements, either using new materials offered by suppliers or under a licensing agreement from the original manufacturers.

The second type of innovation was represented by a case at $\mathrm{CO} 2$, where a spinoff company, called Kalbe Genomics (KalGen) commercialized the results from its Stem Cell and Cancer Institute (SCI). CO2 is a market leader in Indonesia with prominent medicines in different classes of products. After being a follower for quite a long time, $\mathrm{CO} 2$ chose to implement an innovative or technology leader strategy where it pursued the latest technological development and offered products or services using that 
technology. CO2 entered the stem cell and cancer research area.

In the ICT industry, two cases were selected to follow the development of two products that were previously being imported. Incremental innovation was investigated by the development of a critical and highly priced part of a GPS system that is called GPS Time Sync by CO3, while radical innovation was investigated in a case at $\mathrm{CO} 4$, where they developed an interlocking system as the main part of a signaling system that controls all train movements safely and efficiently.

CO3 is a typical company with a follower strategy, which produces products based on market needs in Indonesia. They look for existing equipment and try to redesign and manufacture it in Indonesia. Their main value added is lower pricing compared to the original products. Their goal is to substitute imported products in the high growth ICT industry. partner for some bigger jobs and ended up as a designer and manufacturer of products for railway communication systems. CO4 evolved from being merely a follower into a company with a strong adaptive strategy, in which CO4 looks for existing products with advanced technology and designs, and manufactures them in Indonesia.

\section{Panel of Experts}

This study examined the content validity to determine the feasibility or relevance of cases through a rational analysis by a panel of experts. This procedure provides logical validity on the factors measuring innovation. The researchers worked with a panel of experts, which had excellent knowledge about innovation and the measurement of innovation. The members of this expert panel are researchers from a reputable university and government research institution in Indonesia, five professionals from pharmaceutical and ICT companies in Indonesia, and two

Table 1. Members of the expert panel

\begin{tabular}{lll}
\hline Expert & Type & Organization \\
\hline Expert 1 & Professional & Joint venture Indonesia - Japan Pharmaceutical Company \\
Expert 2 & Academician/Researcher & Technology University \\
Expert 3 & Professional & Pharmaceutical Company \\
Expert 4 & Professional & Pharmaceutical Company \\
Expert 5 & Entrepreneur & Pharmaceutical Company \\
Expert 6 & Professional & Pharmaceutical Company \\
Expert 7 & Researcher & Government Research Institution \\
Expert 8 & Entrepreneur & ICT Company \\
Expert 9 & Professional & ICT Company \\
Expert 10 & Academician/Researcher & Technology University \\
\hline
\end{tabular}

CO4 has a long history, first as a research institution and then as a company for electronics and ICT products. CO4 moved through several roles in its path to become one of the players in the industry. CO4 started as a subcontractor for smaller jobs, as a entrepreneurs (see Table 1). The experts on this panel discussed the activities during the innovation processes and the management of innovation, which were initially identified from the cases. 
Gadjah Mada International Journal of Business - Jammary-April, Vol. 23, No. 1, 2021

\section{Data Collection}

The data sources used primary data and secondary data. The primary data were collected by in-depth interviews with semi-structured techniques and open-ended questions, so that the researchers could explore in more detail the research phenomena under study and gain a broader understanding. Meanwhile, the secondary data were obtained from there was no significant addition of information. The summary of all the interviews, the related documents, and the observations made is collected in Table 2 .

All the interviews were recorded with a digital voice recorder, transcribed, and put into NVivo10 software for analysis. The same was done for all the related documents and observation notes.

Table 2. Details of the case study

\begin{tabular}{|c|c|c|c|}
\hline Company & Interview & Documentation \& Archives & Observations \\
\hline CO1 & $\begin{array}{l}10 \text { interviews with: man- } \\
\text { aging director and head } \\
\text { and staff from business } \\
\text { development unit }\end{array}$ & $\begin{array}{l}\text { Internet documents, photos, } \\
\text { presentations, and a copy of the } \\
\text { company's registration }\end{array}$ & $\begin{array}{l}\text { Staff working space and inter- } \\
\text { action with business develop- } \\
\text { ment group }\end{array}$ \\
\hline $\mathrm{CO} 2$ & $\begin{array}{l}9 \text { interviews with: founder, } \\
\text { director, head of SCI, and } \\
\text { researchers }\end{array}$ & $\begin{array}{l}\text { Internet documents, newsletters, } \\
\text { presentations, annual reports, news- } \\
\text { papers and magazine articles }\end{array}$ & $\begin{array}{l}\text { CO2's head office and SCI's } \\
\text { office and facilities }\end{array}$ \\
\hline $\mathrm{CO} 3$ & $\begin{array}{l}6 \text { interviews with: } \\
\text { co-founders, director, } \\
\text { head of } \mathrm{R} \& \mathrm{D} \text {, and R\&D } \\
\text { engineers. }\end{array}$ & $\begin{array}{l}\text { Internet documents, working order, } \\
\text { company profile, brochures }\end{array}$ & CO3's head office \\
\hline CO4 & $\begin{array}{l}9 \text { interviews with: director, } \\
\text { head of innovation, staff, } \\
\text { and users \& partners }\end{array}$ & $\begin{array}{l}\text { Internet documents, annual reports, } \\
\text { presentations, excerpts of manuals } \\
\& \text { drawings, newsletters, newspa- } \\
\text { pers and magazine articles }\end{array}$ & $\begin{array}{l}\text { CO4's head office and Center } \\
\text { for Technology \& Innovation } \\
\text { and installed interlocking at } \\
\text { Slawi Station }\end{array}$ \\
\hline
\end{tabular}

observations and related documents which included scientific articles, official company data, and information from websites. We built the interview questions based on the framework and asked all the respondents the same questions to analyze their responses regarding the cases studied.

The interviews started with a top manager in the company, to obtain general information on the company's condition and its innovation approach in general. Then, the top manager was asked to connect the researcher with a leader of the innovation project, who in turn suggested the next respondent. Each interview continued with subsequent respondents until saturation was reached, where

\section{Data Analysis}

In the first phase, all the transcripts were read as a whole, after being collected in NVivo10, for gathering the major ideas together and making a case description for each case. Each case description elucidates the case in detail. Using the case description, a within-case analysis was done with the main objective of intimately knowing a particular case and consequently finding insights and some unique patterns or themes from the case through open coding and axial coding (Bernard, 2013). Then a cross-case analysis was done by performing selective coding, wherein the themes were evaluated one more time, together with all the data, so the researchers 
could develop some concepts, which led to the model of innovativeness's measurement for a company. The analyses utilized narrative analysis, in which stories from the case descriptions were evaluated using the following tools: path dependency, periodization, and historical contingency (Bernard, 2013).

In the second phase, the expert panel discussed the measurement factors identified from the cases in Phase 1 and determined the relative importance of the measurement items by assigning their weighing factors . The panel used the analytic hierarchy process (AHP) to determine the factors (Badea et al., 2014). However the AHP evaluations in this research were not done in face-toface meetings but using the Delphi method because it was difficult to arrange a meeting where all the participating experts could attend. The Delphi method is a structured group communication method for soliciting expert opinions about complex problems or novel ideas, through the use of a series of questionnaires and controlled feedback (Day and Bobeva, 2005; Rowe and Wright, 1999). Using the Delphi method avoids the problem of dominance from one or more experts during discussions. Researchers have various opinions of the best number of participants in the Delphi method: as few as three or four up to hundreds or thousands of participants (Rowe and Wright, 1999), 10 to 15 participants (Day and Bobeva, 2005; Phan, 2013), or a minimum of seven participants (Humprey-Murto and de Wit, 2019). All 10 members of the expert panel participated in the discussion on the measurement factors but only seven completed all the steps of the Delphi method.

\section{Findings}

The summary of the activities in the four cases was divided into three innovation

Table 3. Summary of the activities in the four cases

\begin{tabular}{|c|c|c|c|c|}
\hline Phase & CO1 & $\mathrm{CO} 2$ & $\mathrm{CO} 3$ & $\mathrm{CO} 4$ \\
\hline Prior & $\begin{array}{l}\text { Making copies of } \\
\text { medicines and co- } \\
\text { operating with raw } \\
\text { material producers }\end{array}$ & $\begin{array}{l}\text { Making copies of } \\
\text { medicines and coop- } \\
\text { erating with foreign } \\
\text { companies for mak- } \\
\text { ing products }\end{array}$ & $\begin{array}{l}\text { Specializing in the } \\
\text { telecommunications, } \\
\text { computer, and control } \\
\text { technology area and } \\
\text { making a wireless } \\
\text { broadband system }\end{array}$ & $\begin{array}{l}\text { Being a research institu- } \\
\text { tion for electronics and } \\
\text { working on government } \\
\text { funded projects }\end{array}$ \\
\hline Initiation & $\begin{array}{l}\text { Looking for off-pat- } \\
\text { ents, new raw mate- } \\
\text { rials, and licensing } \\
\text { or an exclusive } \\
\text { supply contract }\end{array}$ & $\begin{array}{l}\text { Following the tech- } \\
\text { nology frontier and } \\
\text { doing joint research } \\
\text { or a joint venture }\end{array}$ & $\begin{array}{l}\text { Looking for an oppor- } \\
\text { tunity for an import } \\
\text { substitution and } \\
\text { working to solve the } \\
\text { customer's problem }\end{array}$ & $\begin{array}{l}\text { Looking for the oppor- } \\
\text { tunity of government } \\
\text { funded projects and } \\
\text { participating in a study } \\
\text { group }\end{array}$ \\
\hline Development & $\begin{array}{l}\text { Making, testing, } \\
\text { manufacturing, and } \\
\text { registration of a } \\
\text { new supplement }\end{array}$ & $\begin{array}{l}\text { Researching and } \\
\text { doing clinical trials } \\
\text { on stem cells and } \\
\text { cancer treatment }\end{array}$ & $\begin{array}{l}\text { Defining, designing, } \\
\text { and manufacturing a } \\
\text { GPS-related system } \\
\text { for mobile communi- } \\
\text { cations }\end{array}$ & $\begin{array}{l}\text { Performing the installa- } \\
\text { tion work, and the de- } \\
\text { velopment, engineering, } \\
\text { and manufacturing of } \\
\text { PLC-based interlocking: }\end{array}$ \\
\hline Diffusion & $\begin{array}{l}\text { Launching \& mar- } \\
\text { keting }\end{array}$ & $\begin{array}{l}\text { Commercialization } \\
\text { process (spin-off) } \\
\text { \& offering new } \\
\text { services }\end{array}$ & $\begin{array}{l}\text { Servicing customers: } \\
\text { offering a customized } \\
\text { package for GPS-sync } \\
+ \text { installation and } \\
\text { maintenance }\end{array}$ & $\begin{array}{l}\text { Installing its own PLC- } \\
\text { base interlocking system } \\
\text { and new products' devel- } \\
\text { opment }\end{array}$ \\
\hline
\end{tabular}


Gadjah Mada International Journal of Business - January-April, Vol. 23, No. 1, 2021

phases: initiation-, development-, and diffusion-phase. Table 3 below shows that all the innovation activities in each company had similar activities, though with different contexts. For example, they all formed partnerships: CO1 with a raw materials producer, with Starcom, a mobile operator, to specifically develop the GPS Sync, while CO4, in cooperation with among others Westinghouse, undertook a Centralized Traffic Control (CTC) project in Central Java from 1993 to 1997.

Table 4. General activities during the innovation process in 4 cases in three phases

\begin{tabular}{lll}
\hline Initiation & Development & Diffusion \\
\hline $\begin{array}{l}\text { Building good networks and } \\
\text { working with key opinion leaders, } \\
\text { customers, and the government }\end{array}$ & $\begin{array}{l}\text { Starting initial project with “friend- } \\
\text { ly" customers }\end{array}$ & Bringing the product to market \\
$\begin{array}{l}\text { Getting an understanding of the } \\
\text { products and market }\end{array}$ & $\begin{array}{l}\text { Building manufacturing capabilities } \\
\text { and facilities }\end{array}$ & $\begin{array}{l}\text { Working with other research insti- } \\
\text { tutions }\end{array}$ \\
$\begin{array}{l}\text { Creating a partnership for a specific } \\
\text { purpose: licensing, joint project, or } \\
\text { co-marketing }\end{array}$ & $\begin{array}{l}\text { Doing parts of the complete job, } \\
\text { such as lab testing, clinical trials, } \\
\text { installation and assembly, or me- } \\
\text { chanical jobs }\end{array}$ & $\begin{array}{l}\text { Working with other companies for } \\
\text { solving particular problems }\end{array}$ \\
$\begin{array}{ll}\text { Cooperating with companies in } \\
\text { the group, foreign companies, and } \\
\text { research institutions }\end{array}$ & $\begin{array}{l}\text { Manufacturing with standard oper- } \\
\text { ating procedures }\end{array}$ & $\begin{array}{l}\text { Performing marketing, among oth- } \\
\text { ers brand management tasks }\end{array}$ \\
$\begin{array}{l}\text { Building competences and capabili- } \\
\text { ties in selected products }\end{array}$ & $\begin{array}{l}\text { Doing further research } \\
\text { Assessing financial results: get }\end{array}$ & $\begin{array}{l}\text { Improving and customizing the } \\
\text { products }\end{array}$ \\
& $\begin{array}{l}\text { Suick (intermediate) results } \\
\text { ment new products' develop- }\end{array}$ \\
\hline
\end{tabular}

CO2 with hospitals, $\mathrm{CO} 3$ with its customer, and $\mathrm{CO} 4$ with the interlocking manufacturer and the government. In the development phase, the companies performed trials: CO1 and $\mathrm{CO} 2$ were doing clinical trials or medicine testing, while $\mathrm{CO} 3$ and $\mathrm{CO} 4$ were testing a prototype or a trial initial installation.

The main activities carried out by these four companies were then grouped into general activity classes which were divided into the three innovation phases shown in Table 4. The activity "creating a partnership for a specific purpose" was used to represent the formal co-operation between companies and their respective partners. Some of these activities included CO1 signing an exclusive contract with its supplier DSM Nutritional Products, CO2 participating in joint clinical trials for cancer medicine, CO3 cooperating
The activities in Table 4 were then discussed by the panel of experts and they agreed upon the final grouping of the activities during the innovation process. The technological innovativeness measurement model covered two main areas: the technological innovation process and the management of technological innovation. The technological innovation process consisted of three phases which included initiation, development, and diffusion. In the initiation phase, the panel recognized that the activities could be divided into two groups: the initial preparation to generate ideas (this group of activities was named conceiving ideas) and the activities to work out the ideas (named acquiring information and transforming it into knowledge). In the development phase, the activities were divided into efforts to master and implement 
the technological aspects of the innovation and the business aspects, which included marketing, finance, and operations. In the diffusion phase, the commercialization was divided into earlier activities to get customers' feedback and bigger actions to scale up the production and selling. Meanwhile, the management of technological innovation consisted of several activities which included strategy, resources, and operations. The groups of activities (illustrated in Figure 2), with some details about the specific activities identified from the cases, are explained below. agree. There are several studies describing how to generate ideas. The cases revealed that the following activities are frequently undertaken: building good relations and working with customers and key opinion leaders, looking for trends in technology and products, and cooperating with sister companies within the group of companies.

\section{Acquiring information and} transforming it into knowledge

This phase is important because here the idea is worked out to become an oppor-

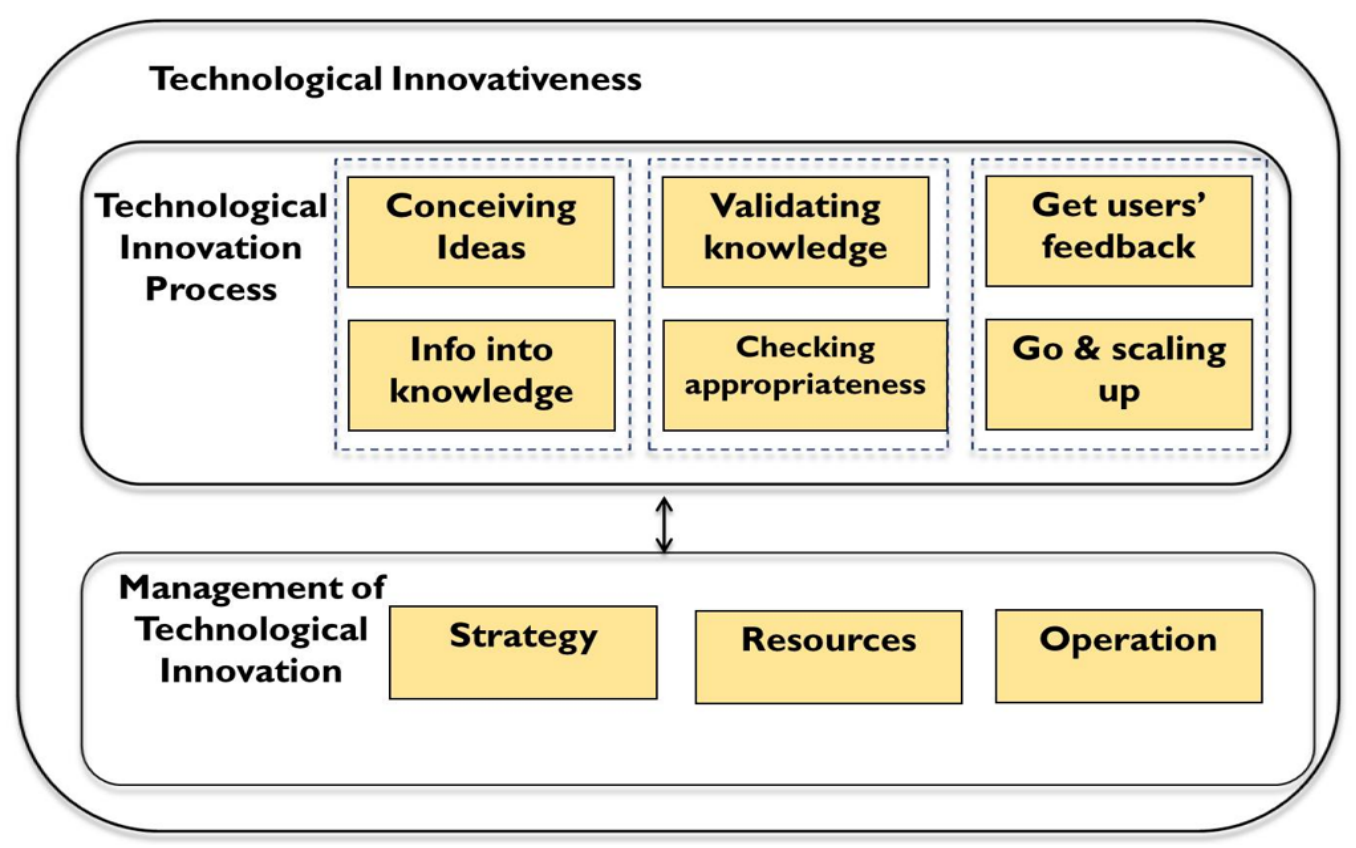

Figure 2. The technological innovativeness measurement model

Based on Figure 2 above, we identified the important steps of each phase. We found activities at each step of these companies as shown below:

\section{A. In the Initiation Phase}

\section{Conceiving ideas}

This phase is one of the important steps in innovation wherein many researchers tunity by cooperating with other companies for specific purposes, for example, being the distributor or doing co-marketing, doing reverse engineering, and performing joint research with universities or other research institutions.

\section{B. In the Development Phase}

3. Implementing and validating knowledge 
In this phase, companies have mastered some technology (knowledge) and they need to prove that they can make something from it. Some companies prefer not to start from scratch and join other companies to make products or parts for them. Here, companies also start building trust with the various stakeholders. Actions to be performed may include making a simple product or parts for it, entering a licensing agreement or performing as a sub-contractor, and performing one activity in the whole value chain for the product's development, such as clinical trials, designing, or parts' manufacturing.

4. Checking the appropriateness of the selected product regarding several aspects in marketing, operation, and finance

Companies need to have a broader view than only about the product. In order to improve the chance that innovation will happen, they need to confirm that the selected innovation candidate is appropriate by undertaking the following actions as well: performing market research, evaluating the technological readiness of the company, including having the required tools and human knowledge and skills, building standard manufacturing and operations practices, and performing financial evaluations.

\section{In the Diffusion Phase}

\section{Commercializing phase 1: Getting customers or users and acquiring their feedback}

The first step in this phase requires companies to find customers so they get money and information for improving the product by: making further prototypes and exploring a variety of features and applications in cooperation with other companies, focusing on low risk low profit projects to build trust and get quick approval, and working on improvements based on the customers' feedback.

\section{Commercializing phase 2: Go and scaling up the project}

In this last phase, companies have to exploit the product further with certain activities: offering products/services more widely through spin-off companies or sister companies, collaborating and benchmarking with the best companies, and building a better supply and distribution channel.

In the area of innovation management, companies have disclosed their practices and concerns with the issues related to: tools \& facilities, and capabilities and competences (such as leadership, rewards, training, governance, external factors, and determining the time of innovation) which are categorized in the following groups:

\section{Strategy}

Activities undertaken are related to a strategy, by being willing to work on small incremental innovations and open to learning about the latest developments, being willing to enter collaborative projects with more advanced companies, and allowing individual-based innovation as well as building the organizational ability to innovate.

\section{Resources}

Activities undertaken are related to resources, which provide the required tools and facilities, are willing to hire experienced 
experts as champions or consultants, and providing projects for employees to further exercise and build their competences.

\section{Operation}

Activities undertaken are related to operations, meaning there are clear instructions from top management to all the companies within the group, a clear and quick decision-making process, and the use of standard procedures.

Based on the results of previous studies, they prove that companies undertake the innovation process with a variety of activities, tools and facilities, and a level of human knowledge, capabilities, and competences. The measurement is then done by evaluating the varieties and the levels in each company. With this approach, the evidence shows that company $\mathrm{CO} 2$, in the past, had a modest laboratory, few scientists, and limited knowledge of formulation. In contrast, during the development of the Stem Cell and Cancer Institute (SCI), CO2 employed people with PhDs in stem cell and cancer research, accumulated knowledge in those areas, and built an advanced lab that received international certification.

\section{Discussions}

This study has identified the management practices and general groups of activities in phases that were well accepted during the innovation process, and which are specific for the Indonesian context, such as conceiving ideas (with sub-activities including cooperating with sister companies within a group) or implementing and validating knowledge (by making a simple product or part for a more complex product, entering a licensing agreement or performing as a sub-contrac- tor) as an initial step to enter the value chain network. The identification of those specific activities is useful to guide Indonesian companies when making innovations and to improve their general type of activities, such as concept generation, product development, process innovation, and technology's acquisition used by Chiesa et al. (1996), knowledge management, project management, and commercialization used by Adams et al. (2006), or ideas' generation, screening, and implementation used by Brophey and Brown (2009). The identification of specific activities is also different to the approach of Essman and du Preez (2009), who instead prescribed the requirements to be fulfilled by the activities, and Rush et al. (2007), who talked about general questions like "awareness of the need to change" and "innovation options."

The measurement framework uses the maturity concept in the following way: First, examine the innovativeness status of a company regarding the extent of its activities of innovation and management practices during the innovation process. Then, evaluate the levels of technological innovativeness by measuring, for example, the state of the company's knowledge, human capabilities, and tools and facilities (shown in Figure 3). The latter are known as the technological system's components (Smith and Sharif, 2007). The use of the maturity concept differs from measurement of the management aspect, such as classifying companies into four types of maturity based on their awareness toward technology's capabilities and changes (Rush et al., 2007), and using the continuum from ad-hoc, limited by its formalization and predictability until integration, synergy, and autonomy (Essman and du Preez, 2009) occur. The concept of maturity that is proposed better differentiates the level of the company's technological innovation. Using the cases 
Gadjah Mada International Journal of Business - January-April, Vol. 23, No. 1, 2021

approach in this study, for example, CO1 and $\mathrm{CO} 2$ undertook similar activities such as partnering, doing research, preparing marketing activities, and performing management activities such as creating a clear decision-making process, using standard procedures, and giving rewards. However, they have different states of their technological systems' compo- operations, and finance related activities. This is in agreement with previous research, which stated that they are essential to capture more innovation activities by the small companies and latecomer companies, who do not always perform formal R\&D activities (Becheikh et al., 2006; Figueiredo, 2014; Smith, 2005; Sutz, 2012).

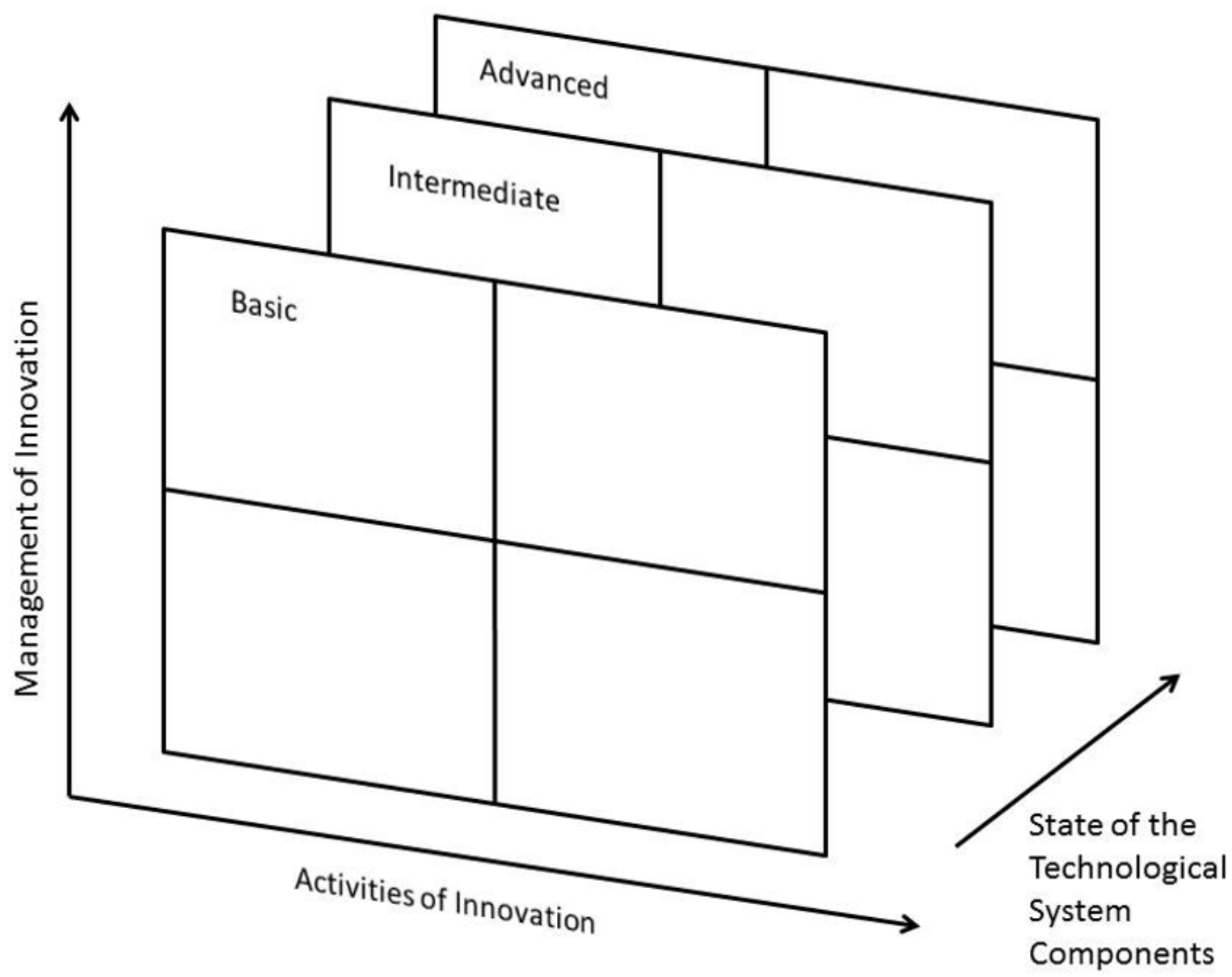

Figure 3. The technological innovativeness status (source: Bell and Figueiredo, 2012; Essman and du Preez, 2009; Rush et al., 2007; Smith and Sharif, 2007)

nents (human resources' qualifications, tools, and facilities), which led to their different innovations: a new supplement and new stem cell \& cancer treatments.

Regarding their types, the identified activities cover a wide range of actions including $R \& D$, non-R\&D, marketing, networking,
The cases have indicated that Indonesian companies initiate innovation by addressing particular customers' needs, which require the creation of simple products or a substitute for the existing imported products. This illustrates the practical approach of innovation, where a company learns about new knowledge or technology and initiates an 
implementation of that knowledge in real projects, starting from simple and small and growing toward more advanced products. This phenomenon is in line with the route of latecomer companies in catching up with others' production capability and then building the innovative capability (Bell and Figueiredo, 2012).

Bell and Figueiredo (2012) have also argued the need to consider both the technological/physical and organizational dimensions to design the activities, put them into operation, and evaluate and readjust them when necessary. Within the management, the strategy-related aspects are found to be more important because they give direction to the company. The implementation is then driven by operational- and resources-related aspects with equal importance. Concerning the activities, this study found that conceiving ideas and getting early customers were the most important ones.

Table 5. AHP Result using Delphi technique

\begin{tabular}{lll}
\hline Criteria & $\begin{array}{l}\text { Weight factor } \\
\text { sub-criteria }\end{array}$ & $\begin{array}{l}\text { Weight factor } \\
\text { criteria }\end{array}$ \\
\hline Activities & & 0.333 \\
\hline Conceiving ideas & 0.225 & \\
Acquiring information & 0.098 & \\
Implementing \& validating & 0.098 & \\
Checking the appropriateness & 0.177 & \\
Commercializing Phase I & 0.225 & \\
Commercializing Phase II & 0.177 & \\
\hline Management of innovation & & \\
\hline Strategy related & 0.500 & \\
Resources related & 0.250 & \\
Operation related & 0.250 & \\
\hline
\end{tabular}

of innovative capability. This study adopts that concept and goes further, to determine the relative contribution of the two dimensions, the activities and the management, to the innovativeness of a company by using the analytic hierarchy process (AHP) to determine the factors based on the perspective of the panel of experts. The level was determined by assessing the contribution of each construct and its factors to add value and reduce costs and increase revenue. The relative importance of the dimensions and their items are collected in Table 5. The contribution of the management (weighted factor $=$ 0.667 ) is considered more important than the contribution of the activities (weighted factor $=0.333$ ) because management is needed
The discussion above shows that the proposed measurement framework has added a tool to measure innovation in those companies focusing on the innovation process. The framework considers the specific activities of innovation and their management, which is an enrichment of the previous process-focused measurement from Adams et al. (2006), Brophey and Brown (2009), and Chiesa et al. (1996). The framework is also an addition to the measurement of the innovation's maturity, following the CMM approach, after the work of (Essman and du Preez, 2009; Rush et al., 2007).

The proposed measurement framework was derived from cases from the pharma- 
ceutical and ICT industries, which have different natures and stages of development. It was also discussed above that the state of the technology in each industry may be different as well. It is important to contemplate that the framework can be accepted in the wider setting of the manufacturing industry and not only in the setting of the pharmaceutical or ICT industries. In the case study approach this principle of "external validity" or "generalizability" is offered by analytical generalization, which is supported by a crosscase analysis involving four to 10 case studies (Eisenhardt, 1989). After finding patterns in the pharmaceutical and ICT industries from the data collected, similarities and differences are examined across cases that lead to a common pattern and some insights about the phenomenon being investigated.

\section{Conclusion and Recommen- dation}

This study has contributed by proposing a measurement framework to measure the technological innovation status of a company through the evaluation of the actual innovation activities and the management of them, which are identified from the empirical evidence, gathered in a multiple case study research. The measurement framework was inspired by the CMM approach, but does not use the maturity as such competences at previous researches . Instead, the maturity represents the status of the technological and management dimensions of the innovation activities. The proposed framework is expected to help companies to understand what they are doing and help them to manage during innovation, evaluate the status, and thereby know how to make improvements. The measurement framework suits the practical approach to innovation, where a company learns about new knowledge or technology and initiates an implementation of that knowledge in real projects, starting from the simple and small and growing toward more advanced products.

The implication of this study for companies and the government is expected to be more substantial. It has been identified that companies need to be included in the value chain, in order to learn the problem, acquire the technology, and produce the product. Therefore, the government has to encourage companies to participate in collaboration projects with leading companies or participate in local, regional, or even global value chains with certain financial support schemes. The government also needs to increase import substitution programs to offer opportunities for local companies to innovate and produce the replacement products. Another area that needs government attention is the creation of several research consortia. Together with the companies, the government has to select the potential technologies to be the topics of research, which should lead to various product or process innovations. The finding of this study should be used as an initial measurement framework for Indonesian manufacturing companies. Although this paper is based on multiple cases from pharmaceutical and ICT companies in Indonesia, the analytical generalization has to be critically accepted and considered to still be limited. Therefore, further research is needed with more cases from other sectors in the manufacturing industry, or quantitative research to develop a clearer understanding and a set of hypotheses that can be tested. In addition, further research is also needed to build the measurement tools for items that are considered important in the technological and management dimension of innovation activities (and therefore need to be measured) to make the proposed framework better and more complete. 


\section{References}

Adams, R., J. Bessant, and R. Phelps. 2006. Innovation Management Measurement: A Review. International Journal of Management Reviews 8(1): 21-47.

Aldianto, L., J.H. Tjakraatmadja, D.Larso, andI. Primiana. 2012, July. A framework to assess technological innovativeness of a company: case studies at Indonesian pharmaceutical industry. In 2012 Proceedings of PICMET'12: Technology Management for Emerging Technologies (pp. 2109-2116). IEEE.

Alegre, J., R. Lapiedra, and R. Chiva. 2006. A Measurement Scale for Product Innovation Performance. European Journal of Innovation Management 9(4): 333-346.

Andrew, J.P., K. Haanaes, D.C. Michael, H.L. Sirkin, and A. Taylor. 2009. Measuring Innovation 2009: The Need for Action. Boston, USA: The Boston Consulting Group.

Arndt, M., and B. Einhorn. 2010. The 50 Most Innovative Companies. Bloomberg Business week, April.

Badea, A., G. Prostean, G. Goncalves, and H. Allaoui. 2014. Assessing risk factors in collaborative supply chain with the analytic hierarchy process (AHP). Procedia-Social and Behavioral Sciences 124: 114-123.

Bature, S.W., R.M. Sallehuddin, N.A. Rosli, and S. Saad, 2018. Proactiveness, innovativeness and firm performance: the mediating role of organizational capability. Academy of Strategic Management Journal 17(5): 1-14.

Becheikh, N., R. Landry, and N. Amara. 2006. Lessons from Innovation Empirical Studies in the Manufacturing Sector: A Systematic Review of the Literature from 1993 - 2003. Technovation 26(5-6): 644-664.

Bell, M., and P.N. Figueiredo. 2012. Building innovative capabilities in latecomer emerging market companies: some key issues. In Innovative Firms in Emerging Market Countries, edited by E.Amann and J. Cantwell. Oxford: Oxford University Press.

Bernard, H. R. 2013. Social research methods: Qualitative and quantitative approaches. Thousand Oaks: Sage Publications.

Brem, A., M. Maier, and C. Wimschneider. 2016. Competitive advantage through innovation: the case of Nespresso. European Journal of Innovation Management 19(1): 133-148.

Brophey, G., and S. Brown. 2009. Innovation Practices within Small to Medium-Sized Mechanically-Based Manufacturers. Innovation: management, policy \& practice 11(3): 327-340.

Capaldo, G., L. Iandoli, M. Raffa, and G. Zollo. 2003. The Evaluation of Innovation Capabilities in Small Software Firms: A Methodological Approach. Small Business Economics 21(4): 343-354.

Chiesa, V., P. Coughlan, and C.A. Voss. 1996. Development of a Technical Innovation Audit. Journal of Product Innovation Management 13(2): 105-136.

Choi, S. B., and C. Williams. 2016. Entrepreneurial orientation and performance: Mediating effects of technology and marketing action across industry types. Industry and Innovation 23(8): 673-693.

Chuang, L.M. 2005. An Empirical Study of The Construction of Measuring Model for Organizational Innovation in Taiwanese High-Tech Enterprises. Journal of American Academy of Business 6(1): 299-304. 
Gadjah Mada International Journal of Business - January-April, Vol. 23, No. 1, 2021

Cooper, R.G., and S.J. Edgett. 2012. Best Practices in the Idea-to-Launch Process and Its Governance. Research-Technology Management, March - April, 43-54.

Dantas, E., and M. Bell. 2009. Latecomer Firms and the Emergence and Development of Knowledge Networks: the Case of Petrobras in Brazil. Research Policy 38(5): 829-844.

Day, J., and M. Bobeva. 2005. A Generic Toolkit for the Successful Management of Delphi Studies. The Electronic Journal of Business Research Methodology 3(2): 103-116.

Didu, S. 2010. 'Interview'. Bisnis Indonesia Daily, April 27.

Dutrenit, G. 2000. Learning and Knowledge Management in the Firm. From Knowledge Accumulation to Strategic Capabilities. Cheltenham, UK: Edward Elgar.

Eisenhardt, K.M. 1989. Building Theories from Case Study Research. The Academy of Management Review 14(4): 532-550.

Essmann, H., and N. du Preez. 2009. An Innovation Capability Maturity Model - Development and Initial Application. World Academy of Science, Engineering and Technology 3(5): 398-410.

Ettlie, J.E., W.P. Bridges, and R.D. O'Keefe. 1984. Organization Strategy and Structural Differences for Radical versus Incremental Innovation. Management Science 30(6): 682-695.

Figueiredo, P.N. 2014. Beyond technological catch-up: An empirical investigation of further innovative capability accumulation outcomes in latecomer firms with evidence from Brazil. Journal of Engineering and Technology Management 31(January): 73-102.

Groenland, E. and Dana, L.P. 2019. Qualitative Methodologies and Data Collection Methods: Toward Increased Rigour in Management Research (Vol. 1). World Scientific, Singapore.

Guo, J., J. Pan, J. Guo, F. Gu, and J.Kuusisto. 2019. Measurement framework for assessing disruptive innovations. Technological Forecasting and Social Change 139: 250-265.

Herrera, M. E. B. 2015. Creating competitive advantage by institutionalizing corporate social innovation. Journal of Business Research 68(7): 1468-1474.

Hinterhuber, A., and S.M. Liozu. 2014. Is innovation in pricing your next source of competitive advantage? Business Horizons 57(3): 413-423.

Houghton, C., D. Casey, D. Shaw, and K. Murphy. 2013. Rigour in qualitative case-study research. Nurse researcher 20(4).

Humphrey-Murto, S., and M. de Wit. 2019. The Delphi method—more research please. Journal of clinical epidemiology 106: 136-139.

Indrayanto, A., J.T. Pramudito, D. Danudirdjo, and A. Handayani. 2008. Evaluation of The Policy on Implementation of Telecommunication Service Providing in The Transition Era, Unpublished document. [In Bahasa Indonesia]

Jugend, D., T.R.D. Araujo, M.L.Pimenta, J.A. Gobbo Jr, and P. Hilletofth. 2018. The role of cross-functional integration in new product development: differences between incremental and radical innovation projects. Innovation20(1): 42-60.

Kim, D. Y., V. Kumar, and U. Kumar. 2012. Relationship between quality management practices and innovation. Journal of operations management 30(4): 295-315.

Martensen, A., J. Dahlgaard, S.M. Park-Dahlgaard, and L. Gronholdt. 2007. Measuring and Diagnosing Innovation Excellence - Simple Contra Advanced Approaches: A Danish Study. Measuring Business Excellence 11(4): 51-65.

Menguc, B., S. Auh, S., and P.Yannopoulos. 2014. Customer and supplier involvement in design: The moderating role of incremental and radical innovation capability. Journal of Product 
Innovation Management 31(2): 313-328.

Ministry of Industry. 2013. Assessing the Readiness of National Industry Toward AEC 2015. Media Industri, Jakarta. [In Bahasa Indonesia]

OECD. 2005. Oslo Manual. Paris: European Commission/Eurostat.

Paik, J., and H.J. Chang. 2015. Post-Catch-Up Strategy for Medium-Sized South Korean Firms: Improving Technological Capabilities by Balancing R\&D Intensity and Open Innovation. Engineering Management Journal 27(4): 164-176.

Phan, K. 2013. Innovation Measurement: A Decision Framework to Determine Innovativeness of a Company. Unpublished PhD Dissertation. Portland State University.

Phan, K., and D.F. Kocaoglu. 2014, July. Innovation measurement framework to determine innovativeness of a company: Case of semiconductor industry. In Proceedings of PICMET'14 Conference: Portland International Center for Management of Engineering and Technology; Infrastructure and Service Integration (pp. 747-757). IEEE.

Read, A. 2000. Determinants of Successful Organizational Innovation: A Review of Current Research. Journal of Management Practices 3(1): 95-119.

Rowe, G., and G. Wright. 1999. The Delphi Technique as a Forecasting Tool: Issues and Analysis. International Journal of Forecasting 15(4): 353-375.

Rush, H., J. Bessant, and M. Hobday. 2007. Assessing the Technological Capabilities of Firms: Developing a Policy Tool. R\&D Management 37(3): 221-226.

Sampurno. 2007. Technological Capability and R\&D Strengthening: A Pharmaceutical Industrial Challenge in Indonesia. MajalahFarmasi Indonesia 18(4): 199-209. [In Bahasa Indonesia]

Saunila, M., and J. Ukko. 2012. A Conceptual Framework for the Measurement of Innovation Capability and Its Effects. Baltic Journal of Management 7(4): 355-375.

Sheng, M. L., \& I. Chien. 2016. Rethinking organizational learning orientation on radical and incremental innovation in high-tech firms. Journal of Business Research 69(6): 2302-2308.

Silva, F. S., F.S.F. Soares, A.L. Peres, I.M. de Azevedo, A.P.L. Vasconcelos, F.K. Kamei, and S.R. de LemosMeira. 2015. Using CMMI together with agile software development: A systematic review. Information and Software Technology 58: 20-43.

Smith, K. 2005. Measuring Innovation. In The Oxford Handbook of Innovation, edited by J. Fagerberg, et al. Oxford: Oxford University Press.

Smith, R., and N. Sharif. 2007. Understanding and acquiring technology assets for global competitions. Technovation 27(11): 643-649.

Smith, S., G. Smith, and Y.T. Shen. 2012. Redesign for product innovation. Design Studies 33(2): 160-184.

Sutz, J. 2012. Measuring Innovation in Developing Countries: Some Suggestions to Achieve More Accurate and Useful Indicators. International Journal of Technological Learning, Innovation and Development 5(1/2): 40-57.

Tetnowski, J. 2015. Qualitative case study research design. Perspectives on Fluency and Fluency Disorders 25(1): 39-45.

Tsao, S. M., and G.Z. Chen. 2012. The impact of internationalization on performance and innovation: The moderating effects of ownership concentration. Asia Pacific Journal of Management29(3): 617-642.

Tushman, M.L. and Romanelli, E. 1985. Organizational evolution: A metamorphosis model of 
Gadjah Mada International Journal of Business - January-April, Vol. 23, No. 1, 2021

convergence and reorientation. Research in organizational behavior.

Tushman, M.L. and Anderson, P. 1986. Technological discontinuities and organizational environments. Administrative science quarterly: 439-465.

World Bank. 2012. Policy Note 1: Why the Manufacturing Sector Still Matters for Growth and Development in Indonesia. Jakarta: The World Bank Office.

World Bank. 2019. Current health expenditure per capita (current US\$). [Online] Available at https://data.worldbank.org/indicator/SH.XPD.CHEX.PC.CD, accessed November 2019.

World Economic Forum. 2019. The Global Competitiveness Report 2018 - 2019. Geneva: WEF.

Wu, W., B. Yu, and C. Wu. 2012. How China's equipment manufacturing firms achieve successful independent innovation: The double helix mode of technological capability and technology management .Chinese Management Studies 6(1): 160-183.

Yin, R.K. 2014. Case Study Research; Design and Methods. Los Angeles, CA: Sage. 